\title{
Comparative Study on The Contribution Payment System in BPJS With A Tax System-Based Regulation In NHS
}

\author{
Made Cinthya Puspita Shara \\ Universitas Indonesia, Depok-Indonesia \\ cinthyapuspita@gmail.com
}

Published: 25/02/2021

\begin{abstract}
How to cite:
Shara, M. C. P. (2021). Comparative Study on The Contribution Payment System in BPJS With A Tax System-Based Regulation In NHS. Sociological Jurisprudence Journal. 4(1). Page 45 - 53. https://doi.org/10.22225/scj.4.1.2308.45-53
\end{abstract}

\begin{abstract}
The purpose of this paper is to examine the efficiencies of United Kingdom life insurance, which is regulated in the NHS with a tax-based funding system. The effectiveness of the Health Insurance System, will provide better health services for the people. Currently, there are still many complaints in the BPJS service system, such as late payments for hospitals and salaries for medical personnel. This study will use the comparative law method, by comparing the BPJS system in Indonesia with the NHS health insurance system in the UK. BPJS uses a monthly fee funding system, the amount of payment are depends on the types of class that BPJS participants has taken. Whereas the NHS only uses a tax-based funding system, where the use of this system can effectively meet all health service needs maximally. Based on the results of research on OECD countries, it is revealed that the taxbased social health insurance program tends to be more progressive and fair. Based on this comparative study, it is important for Indonesia to improve its health insurance system arrangements in order to adapt the tax-based funding system.
\end{abstract}

Keywords: Health Insurance; Funding System; Health Services.

\section{INTRODUCTION}

The increasing public awareness of health costs can be seen from the high public registration as BPJS participants in Indonesia (INFOBPJS Kesehatan, 2019). Recognizing this, the Indonesia Government must be able to maintain and provide welfare to the community by building a health insurance system that can be utilized properly by its people. The provision of health insurance by the government is a form of social security, the meaning of Social Security comes from since 1948 on UN Declaration on Human Rights at the ILO Convention Number 102 year 1952. Social Security is a form of social protection administered by the State to ensure that its citizens meet the basic needs of a decent life. The regulation in Indonesia regarding social security is contained in the basis of its Constitution as an effort to prosper the people, one of its forms is through health insurance which is the duty of the Government of the State of Indonesia. In the provisions of Law Number 36 Year 2009 concerning Health, which states that everyone has the same rights to safe, quality, and affordable health. Referring to this explanation, it can be seen that the State has an obligation to provide certain services and rights in the health sector, which must be supported by a system that can realize adequate and affordable health services.

BPJS (Badan Penyelenggara Jaminan Sosial), formed based on Undang-Undang Nomor 40 Tahun 2004 Tentang Sistem Jaminan Sosial Nasional and Undang-Undang Nomor 24 Tahun 2011 tentang Badan Penyelenggara Jaminan Sosial. As a health distribution tool that provides quality and affordable health for the community. However, in practice BPJS still has complex and unsatisfactory problems. Lack of budget, services that are considered too complicated or unpleasant, to experts who feel that the rewards are not worth the effort they do. There is news circulating that there are still hospitals that are not paid by BPJS, which costs for health services, medicines, and also medical personnel services 
(CNN, 2019). There are many hospitals that still refuse BPJS participant patients, on the grounds that the hospital does not have an empty room (Amalia, 2019). This is because the hospital does not want to suffer losses, where BPJS claims with a 14 day maturity date will affect the hospital's liquidity. As the impact of the hospital refusal from BPJS patients is the worsening of the patient's health condition, and this shows the weakness of the service system by BPJS Kesehatan. Seeing these weaknesses, the writer feels that it is necessary to study social security systems in other countries, to be used as lessons in the mechanism of social security reform in Indonesia.

Indonesia is currently struggling to improve its health service system, so it is necessary to study the comparison of the system with other countries. This is deemed necessary in order to minimize its impact on people's health. In general, the national health insurance system in the world can be divided into 4 types, namely the concept of private insurance with government subsidies (traditional sickness insurance), the concept of the government to finance national health insurance (national health insurance), the concept of providing health services by the government (national health service) and mixed between traditional financing and national health financing (health insurance and health services) (Thabrany, 2003).

As a comparison, this paper will refer to the NHS (National Health Service) system which is a social security system in the United Kingdom. Unlike Indonesia, the NHS operates by using tax raising as a source of funds. The establishment of the NHS is based on the principle that health social security services must meet the needs of all members of society, free of charge and based on needs, not the ability of an individual to pay for services. The use of the term NHS itself can refer to each of the different institutions that provide social health insurance in each member state of the United Kingdom, but the NHS can also refer to the entire system collectively. As a form of delegation of power, each agency operates independently from other NHS agencies and is responsible to the government concerned; NHS Wales to the Government of Wales, NHS Scotland to the Government of Scotland, NHS of Northern Ireland to the Government of Northern Ireland and NHS England to the Government of Great Britain (NHS Guidance, 2015).

The health social security system administered by the NHS is considered a successful and wellfunctioning system (Pavolini, 2012). A study conducted by the World Health Organization (WHO) in 2010, put the UK's health insurance system in the 18th best out of 190 countries, besides that several medical journal sites also conducted an assessment study of health social security systems in 11 developed countries, where the UK system was rated as the best (Suhanda, 2015).

\section{METHOD}

This research uses legal research methods with normative studies. Legal research is a process of finding legal rules, legal principles, and legal doctrines in order to address legal issues at hand (Marzuki, 2013). The approaches used are the conceptual approach, statue approach, and comparative approach. As a primary source of law in this study, it uses laws and regulations relating to social security and health. As secondary legal material in this research, books, scientific journals, papers and scientific articles can provide clarity about primary law. Whereas in the use of tertiary legal materials in this study, writers use the black law dictionary to find legal terms related to the discussion. The collection of legal materials was carried out by the author in this study by conducting research on e-learning media, and literature through the University of Indonesia library in the form of e-books, in order to find relevant sources that can be used in the discussion of public health social security. In writing, a system is used to analyze primary legal materials, secondary legal materials, and tertiary legal materials, which then draw conclusions from the processing of the three legal materials.

\section{RESULT AND DISCUSSION}

\section{Regulation and Role of Badan Penyelenggara Jaminan Sosial Kesehatan (BPJS)}

During the reform period, the concept of national health insurance in Indonesia began to develop, with the term Sistem Jaminan Sosial Nasional (SJSN). Starting with the initiation of this concept by the President Abdurahman Wahid and DPR for the immediate establishment of the Social Security Administering Body in 2000 (BPPN, 2015). A year later, in the next presidential term, President Megawati Soekarno Putri formed the SJSN working group to formulate the Academic Paper for the 
RUU SJSN. The MPR also amended the 1945 Constitution in the same year. One of the amended articles is Article 34 paragraph (1) and (2) which mandates the development of a National Social Security System. In accordance with this mandate and after receiving many changes and improvements, Law no. 40 of 2004 concerning the National Social Security System was officially handled on 19 October 2004. The social security program that is mandated to be run consists of five programs, namely Health Insurance, Work Accident Insurance, Old Age Security, Death Security and Pension Security. In order to carry out these programs, the SJSN Law mandates the establishment of the Social Security Administration (BPJS) and the National Social Security Council (DJSN). Through Presidential Decree No. 110 of 2008, the DJSN was officially formed on 24 September 2008. The process of drafting the BPJS Law did not run smoothly, so it was not formulated until the deadline for the transition of the SJSN Law in 2009. Basically, the formation of BPJS Kesehatan aims to improve the welfare of the community in the health sector and make it happen through a system that is open and easily accessible to all members of society. In Article 4 regarding Undang-Undang No. 24 Tahun 2011 about BPJS, explained nine basic principles in the administration of BPJS Kesehatan, namely, mutual cooperation, non-profit, openness, prudence, accountability, portability, mandatory membership, funds and mandate, the results of the management of health insurance funds are used entirely for program development and for the greatest interest of the participants.

Peraturan Presiden No. 12 Tahun 2013, regulates BPJS membership. Participants who are entitled to receive BPJS contribution assistance are known as PBIs, which are health insurance payment assistance provided to people who are classified as poor and needy. Non-PBI participants are participants who are not classified as poor and underprivileged (BPJS Kesehatan, 2014). As ownership rights over BPJS participants, all participants will get a participant card that can be used to obtain health services, obtain benefits and information about rights and obligations. Other uses of the BPJS card are to access health service procedures in accordance with applicable regulations, namely getting health services at health facilities in collaboration with BPJS Kesehatan, and submitting complaints / complaints, criticisms and suggestions verbally or in writing to the BPJS Health Office. The obligations as a BPJS participant are to register themselves as participants and pay dues in accordance with applicable regulations, report changes in participant data, whether due to marriage, divorce, death, birth, changing addresses or moving first-level health facilities, maintaining Participant Cards from damage, loss or use by unauthorized persons, and comply with all provisions and procedures for health services.

Based on article 10 Undang-Undang No. 24/2011 regulates the functions of the BPJS, namely to conduct and/or receive participant registration, collect and collect contributions from participants and employers, receive contribution assistance from the Government, manage Social Security funds for the benefit of participants, collect and Managing data on social security program participants, paying benefits and / or financing health services in accordance with the provisions of the social security program, and providing information on the implementation of social security programs to participants and the public. In this provision, it can be seen that the BPJS has a fairly important role in society, which in its implementation requires quite high operational costs. The number of costs that must be incurred by the BPJS in order to realize the best health services for the community.

The authority of the BPJS is regulated in article 11, namely, there are eight main tasks, first, to collect payment of contributions. Second, placing the Social Security Fund for short-term and long-term investments by considering aspects of liquidity, solvency, prudence, security of funds, and adequate returns. Third, supervise and examine the compliance of participants and employers in fulfilling their obligations in accordance with the provisions of the national social security legislation. Fourth, make an agreement with health facilities regarding the amount of payment for health facilities that refers to the standard tariff set by the Government. Fifth, creating or terminating employment contracts with health facilities. Sixth, impose administrative sanctions on participants or employers who do not fulfill their obligations. Seventh, reporting employers to the competent authority regarding their non-compliance in paying contributions or in fulfilling other obligations in accordance with the provisions of laws and regulations. Eighth, collaborating with other parties in the context of administering social security programs. When exercising the authority, the BPJS has a high enough risk, from the unstable investment value to the changing state of medical costs during the outbreak.

Discussion of the rights and obligations of the BPJS, in which the BPJS has twelve obligations and 
two rights based on the BPJS Law. The obligations of the BPJS are regulated in article 13 UndangUndang No. 24 Tahun 2011, including providing a single identification number to participants, developing Social Security Fund and BPJS assets, providing performance information, providing benefits to all participants, providing information on participant rights and obligations, providing information on how to obtain rights and fulfillment of obligations, provide balance information, provide information on pension rights, form technical reserves according to standards, carry out bookkeeping, report on the implementation of each program, and these obligations are related to the governance of BPJS as a public legal entity. Meanwhile, the rights of BPJS are regulated in Article 11, which states that BPJS has the right to obtain operational funds for the implementation of programs sourced from social security funds or others in accordance with the provisions of laws and regulations. Another right is to obtain the results of monitoring and evaluation of the implementation of the social security program from the DJSN (Ardiansah \& Oktapiani, 2020). The high burden of liabilities that BPJS currently has is not balanced with the accuracy of payments to hospitals and medical personnel. There are still many complaints from the public who convey their rejection of BPJS treatment. This can happen because the BPJS is slow in providing reimbursement of funds and payments to hospitals and medical personnel.

The supervision of the BPJS is divided into two, namely, internal and external supervision. Internal supervision The supervision is carried out by the BPJS organ or by the internal control unit formed by the BPJS organ which is authorized to determine the organizational structure. Or in other words, internal supervision is carried out by an organ or supervisory task force within the BPJS organ itself. BPJS internal supervision is carried out by the BPJS supervisor which consists of Article 39 paragraph (2) of Law no. 24 of 2011. The Supervisory Board of BPJS is an organ of the BPJS that functions to carry out supervisory duties on the implementation of BPJS duties. Meanwhile, the internal supervisory unit was formed as a special unit to assist and on behalf of the top leadership to supervise all organizational units within the BPJS. Internal supervision carries out functional supervision in accordance with their respective areas of duty in order to assist leaders in managing the organization to achieve predetermined goals. Meanwhile, external supervision is supervision carried out by institutions from outside the BPJS. According to Article 39 paragraph (3) Undang-Undang No. 24 Tahun 2011 conducted by the DJSN and independent institutions such as OJK. The Supreme Audit Agency (BPK) can conduct audits (Elucidation of Article 39 paragraph (3) letter b of Undang-Undang No. 24 Tahun 2011). OJK functions to organize an integrated regulatory and supervisory system of all activities in the financial services sector.

\section{Regulation and Role of the National Health Service (NHS)}

In 2011, the UK Ministry of Health passed the NHS Constitution governing the basic principles of the NHS (NHS Guidance, 2012). The first principle, the NHS provides comprehensive services that are available to all members of society. Services are designed to improve, prevent, diagnose and treat physical and mental health problems. Access to NHS services is based on need, not an individual's ability to pay. The NHS service does not charge a fee, except under certain conditions regulated by Parliament. The NHS values quality and professionalism. Patients are of primary importance, with the NHS having to support individuals to manage their own health. The NHS works across organizational boundaries to improve its services. The NHS is committed to managing tax money funds well. The NHS is committed to managing limited resources effectively, and fairly. Funds for health care will only be used for the benefit of the people the NHS serves. The NHS is accountable to the public and the patients it serves. The NHS is a national service that is funded through national taxes, and it is the government that sets the framework for the NHS and is responsible to Parliament for its operations. However, most decisions in the NHS, especially regarding individual care and detailed service organizations, are properly taken by the local NHS and by patients and their doctors. The system of responsibility and accountability for making decisions in the NHS must be transparent and clear to the public, patients and staff. The Government will ensure that there is always a clear and current statement of NHS accountability for this purpose.

Access to the NHS is universal, but also depends on a person's immigration status in the UK. Fees may be charged to access certain services, however, there are certain services that will be free of charge for anyone, namely care by the emergency accident department which does not include further treatment after admission to hospital, treatment for certain infectious diseases, psychiatric care, and family 
planning services. There are rights and obligations in using NHS services. The rights to be obtained include, access to services, quality care and environment, drug treatment and state-approved programs, consent and confidentiality, choice, involvement in health care, to complaints and compensation (Rachmawati, 2010).

Meanwhile, obligations must be done because the NHS is a shared service. This obligation is regulated in the NHS constitution to ensure that the service system works effectively and resources are used responsibly. First, the obligation to realize that each person can make a significant contribution to himself, and his family regarding health. Second, the obligation to register with a general practitioner. Third, the obligation to treat NHS staff and other patients with respect. Everyone should be aware that abusive behavior can lead to denial of service fees. Fourth, the obligation to provide accurate information about health, condition and status. Fifth, the obligation to honor appointments or cancel with reasonable conditions. Sixth, the obligation to follow a series of treatments that have been approved, and communicate with doctors about difficulties that may be found. Seventh, the obligation to participate in important public health programs such as vaccinations. The final obligation is that if you wish to donate organs, it is obligatory to notify family members and those closest to them.

\section{Comparative Analysis between BPJS and NHS Health Insurance Systems}

The purpose of the BPJS program is to meet the needs of health services for the Indonesian people. Through the contribution payment mechanism, BPJS can provide health services to the public. As public health insurance, this system will provide preventive, curative and rehabilitative health services. These services also include the right to obtain medicines and use certain medical equipment. These facilities can be obtained for BPJS participants. In the provisions of Article 4 of Undang-Undang Nomor 24 Tahun 2011 concerning BPJS, it regulates compulsory BPJS participation. Every member of Indonesian society, including foreigners who have worked for at least 6 (six) months in Indonesia must register as a Jaminan Kesehatan Nasional (JKN) participant. To ensure adequate and sustainable financing, participants are also required to contribute through premium payments. The amount and mechanism of premium payment are adjusted to the type of JKN membership. JKN participants and memberships are regulated in Presidential Regulation No. 12/2013. According to the Presidential Decree, JKN participants include PBI and Non-PBI.

Meanwhile, participation in the NHS system is based on where a person lives, and not on his citizenship status. In general, all residents of the UK are entitled to free treatment. It is the duty of the hospital providing care to ensure that patients qualify for free health care. People who are considered to be permanent residents or "ordinarily residents" in the UK are entitled to free treatment by a general practitioner. A person can be said to be an "ordinarily resident" if he has legally resided in England for the purpose of staying for a certain period of time. Anyone who comes to live in the UK will qualify as an "ordinarily resident". Overseas visitors are not considered permanent residents if they do not meet these requirements. There are also several free services that will not cost anyone, such as emergency accident care, treatment of certain infections, psychiatric care and family planning services.

Based on this explanation, it can be seen that for participation in the two countries, both the NHS and the BPJS both require participation from residents of their countries, including resident foreign nationals. BPJS requires participants to contribute by paying a premium. In this case, there are two categories of BPJS participants, namely PBI (Contribution Assistance Recipients), whose fees are borne by the government, and non-PBI, generally for community members who are not classified as poor. Meanwhile, the NHS system is a tax-based system, where NHS funds are obtained through general taxation and National Insurance contributions as the main source of funds, without premiums. The NHS meets the definition of universal coverage, as defined by WHO. There is a difference between the NHS and the BPJS, where in some NHS services they provide it for free without any cost regardless of citizenship status.

Based on the variety of services provided by the BPJS, ensure that participants are entitled to promotive, preventive, curative and rehabilitative health services at primary and advanced health care centers, including in providing assistive devices for persons with disabilities. There are two types of services provided by BPJS, both medical and non-medical such as ambulances. Health services by BPJS Kesehatan are divided into two, consisting of first-level or non-specialized services, and advanced-level 
services. At the first level of service, this applies to non-specialized health services, while for the second level health service is an advanced level referral health service. Furthermore, it is related to health facilities in the BPJS system, where BPJS Kesehatan pays to the first level Health Facilities with capitation. For advanced level referral health facilities, BPJS Kesehatan pays using the INA CBG package system (Pramana, Arso., \& Kusumastuti, 2018).

All BPJS Health Facilities are obliged to serve patients in emergency situations, this includes health facilities that do not collaborate with BPJS. BPJS Kesehatan is obliged to pay Health Facilities for services provided to Participants no later than 15 (fifteen) days after receipt of complete claim documents. The amount of payment to Health Facilities is determined based on an agreement between BPJS Kesehatan and the Association of Health Facilities in the area by referring to the tariff standard set by the Minister of Health. There are classes in the BPJS if you want accommodation at a higher cost. As a form of accountability for the implementation of its duties, BPJS Kesehatan is obliged to make program management reports and annual financial reports.

Whereas in the NHS, hospitals are managed by trusts and provide all secondary care services in the NHS. Trusts also manage a number of small facilities without inpatient beds, and provide specialized care such as geriatric services and surgical services. Secondary Trusts also provides sexual disease treatment through genitourinary medicine clinics. Public health services are provided by a consultant general health practitioner employed by Primary Trusts. Of the rest, there are about 190 private hospitals in the United Kingdom and 17500 nursing homes. Primary care services are also locally based services that serve as the first, and sometimes the only, form of contact among patients with the NHS. These services include those provided by general practitioners, district nurses, visitor nurses, pharmacists, dentists, midwives and ophthalmologists. Meanwhile, in secondary care, it provides services by practitioners who are not the patient's first contact, and services that can not be provided by general practitioners. The services provided by secondary care services include special care, surgery, specialist clinics such as kidney clinics, rehabilitation services, transportation, and mental health services. So based on this idea, NHS participants do not need to have trouble dealing with insurance agencies, or think about additional expenses if they want to carry out treatment and so on.

Based on this explanation, it can be seen that both of them aim to provide health services that are promotive, preventive, curative, and rehabilitative to the community. In the BPJS Kesehatan system, health services are divided into two, namely first-level or non-specialized services, and advanced-level services. A similar system is also known in the administration of the NHS, where there is a first level service known as Primary Care. At the primary care level, patients see a general practitioner as a form of first contact. If the general practitioner feels that the primary care service cannot meet the patient's needs, the general practitioner can refer to Secondary Care. In general, NHS and BPJS Health both provide a broad, comprehensive range of services covering a variety of treatments for various medical problems. There are several forms of services provided by the NHS but not provided by the BPJS, such as care services for victims of suicide attempts. If the BPJS wants to provide rehabilitative services, then it should not limit the provision of care to victims of suicide attempts, where these actions have an effect on mental illness and psychological disorders.

Observe from the funding and contribution systems in the BPJS and NHS. Funding for the BPJS comes from three main sources, including participant contributions, investment returns and government fund allocations. Meanwhile, most NHS funding comes from general taxation and National Insurance contributions. Contributions in the BPJS system are administered in the form of 'premium payments.' Participants who are categorized as members of the Health Insurance Contribution Beneficiary (PBI) will be paid by the Government. Contributions for employees who work for Government Institutions consist of Civil Servants, TNI members, Polri members, state officials, and non-civil servant government employees, the contribution is $5 \%$ (five percent) of the salary or wages received per month, provided that 3\% (three percent) is paid by the employer and $2 \%$ (two percent) is paid by the participant. Contribution for Wage Recipient Workers who work in BUMN, BUMD and private is $4.5 \%$ (four point five percent) of the monthly salary or wages provided that $4 \%$ (four percent) paid by the Employer and $0.5 \%$ (zero point five percent) paid by the Participant Contribution for the additional family of a Wage Recipient Worker consisting of the fourth child and so on (such as father, mother and / or in-laws), is subject to a contribution of $1 \%$ (one percent) of the salary or wages per month, paid by the worker who 
receives the wage. Meanwhile, contributions for other relatives of wage earners (such as siblings / inlaws, household assistants, and so on). BPJS class 1 contribution Rp. 80.0000, - (eighty thousand rupiah), for class 2 in the amount of Rp. 52,000, - (fifty two thousand rupiah), and for class $3 \mathrm{Rp}$. 25,500, - (twenty five thousand rupiah). Recipient Workers who are late in paying contributions will be subject to an administrative fine of $2 \%$ (two percent) per month of the total outstanding contributions for a maximum period of 3 (three) months (Widiastuti, 2018).

Comparison with the NHS regulatory system, most of the funding comes from general taxation and the contribution of National Insurance, a tax system that is devoted to funding public welfare programs by the Government. Some of the funds are also obtained through user fees or fees for participants, such as costs for prescription drugs, dental care, and eyeglass care. It only accounts for a small portion of NHS funding. In 2015/2016, prescription drug revenues were recorded at $£ 1.3$ billion (pound sterling). This amount only covers $1.1 \%$ of the total budget. In addition, the NHS can also generate income, such as through parking fees or land sales. Each year, the central government determines the level of NHS funding through the Spending Review process. This process is to estimate some amount that will be received for funding through National Insurance contributions, general taxation, and user fees. If National Insurance or retail raises less than estimated funds, then the contribution from general taxation is used to ensure NHS funds reach a predetermined figure. Although the NHS is known as one of the best health social security systems in the world, the funds for the NHS are relatively small compared to the funds held by other health social security administering bodies in surrounding countries. United Kingdom is recorded to have spent around $8.3 \%$ of its GDP (Gross Domestic Product) on social health insurance. This figure puts NHS spending in the thirteenth lowest of EU member states.

Based on the explanation above, it can be seen that health service funding for BPJS comes from three main sources, including participant contributions, investment returns and government fund allocations. Participants in BPJS other than the PBI category are required to pay dues, and the amount of fees paid depends on the level of service class desired by the participant. Meanwhile, the NHS health insurance system is financed through the state budget, which mostly comes from general taxes (tax-funded). In conclusion, the most important difference between the two systems is that the health social security system administered by BPJS is an insurance-based health service system or Social Health Insurance, while the health social security system in the UK is a tax-based system or the Tax Financed Health System. Both systems are used by different countries and are popular in both developing and developed countries. The debate about the effectiveness of these two types of systems is often the subject of discussion of social security experts in the world.

There are two conflicting opinions. Opinions for those who oppose the insurance system argue that the health insurance system makes companies reluctant to add employees, thereby narrowing employment and encouraging the informal labor market. This has an impact on the variety of services provided, to the extent that differences in service quality are seen as a barrier to participant registration. On the other hand, insurance proponents argue that additional sources of funding are essential for the health system. Separating the activities of buyers, health care providers, service providers, and conducting selective partnerships with health service providers (including those in the private sector). However, a study conducted by the World Bank concluded that insurance-based systems were generally more expensive and not as effective as tax-based systems (Blendon, 2010).

Several OECD (Organization for Economic Cooperation and Development) countries reveal that countries with insurance-based systems have an average of 3-4\% (three to four) higher total expenditures for health insurance needs than tax-based systems, and with employment the formal sector is $8-10 \%$ (eight to ten) smaller. With regard to service quality, there is no evidence to suggest that an insurance-based system provides a more effective service. In the aspect of participant satisfaction, the Commonwealth Fund conducted a survey on the satisfaction level of the health insurance system which was attended by 3500 people, including participants and workers, from 11 different countries. According to the survey results, the insurance-based system achieved the highest satisfaction rate at an average of 60 (sixty) percent, and only three percent felt that the system needed total reform. This figure is positive when compared to the satisfaction level in insurance-based countries, namely only $42 \%$ (forty-two) for France, 38\% (thirty-eight) for Germany, 51\% (fifty one) for the Netherlands, and $46 \%$ (fourty six) for Switzerland. In addition, research by Universidad de Antioquia concluded that tax-based social health 
insurance programs tend to be more progressive and equitable.

\section{CONCLUSION}

There are several differences and similarities between the BPJS social security in Indonesia and the NHS in the UK. BPJS requires every member of the public to become a participant, including foreigners who work in Indonesia for a minimum of 6 (six) months. Meanwhile, the NHS membership is similar in that it applies to any "ordinarily resident" with universal coverage based on coverage, while for certain infectious diseases, psychiatric care and family planning services are available free of charge regardless of nationality. The two levels of health services are similar, the BPJS consists of first-level services and advanced-level referrals. Meanwhile, the NHS uses primary care and secondary care. The difference is clearly visible in funding, where in BPJS funds come from participant contributions, investment returns and fund allocations. Meanwhile, in the NHS, funds come from general taxation and the contribution of national insurance. The contribution to the BPJS is in the form of a premium, which is obligatory for residents who are not classified as PBI, and the amount of the fee depends on the class taken. Whereas in the NHS, there are no dues based on taxes alone. Based on the results of research on OECD countries, it is revealed that social health insurance programs with tax-based financing tend to be more progressive and fair.

\section{REFERENCE}

Marzuki, P. M. (2013). Penelitian Hukum, Edisi Revisi, Cetakan Ke-8. Jakarta: Kencana Prenada Media Group.

Thabrany, H. (2003). Tinjauan Akademis Tentang Asuransi Kesehatan Nasional. Jakarta: Pusat Kajian Ekonomi Kesehatan Universitas Indonesia.

Amalia, Y., \& Sari, H. R. (2017). Dalih Rumah Sakit Sering Tolak Pasien Peserta Bpjs, Jakarta: Merdeka. Retrieved from Https://Www.Merdeka.Com/Peristiwa/Dalih-Rumah-Sakit-Sering-Tolak-Pasien-PesertaBpjs.Html.

Ardiansah., \& Oktapani, S. (2020). Politik Hukum Pemenuhan Hak Atas Kesehatan Rakyat Indonesia Berdasarkan Uu Sjsn Dan Uu Bpjs. Jurnal Ius Kajian Hukum Dan Keadilan, 8(1), pp. 161-179. Retrieved from Http:// Dx.Doi.Org/10.29303/Ius.V8i1.707

Blendon, R. J., Benson, J. M., SteelFisher, G. K., \& Connolly, J. M. (2010). Americans' conflicting views about the public health system, and how to shore up support. Health Affairs, 29(11), 2033-2040. Retrieved from https://doi.org/10.1377/hlthaff.2010.0262.

Badan Perencana Pembangunan Nasional (BPPN). (2015). Satu Tahun Pelaksanaan Jaminan Kesehatan Nasional, Jakarta: Direktoran Perlindungan dan Kesejahteraan Masyarakat.

BPJS Kesehatan. (2014). Paduan Praktis Tentang Kepersetaan Dan Pelayanan Kesehatan Oleh BPJS Kesehatan Berdasarkan Regulasi Yang Sudah Terbit.

CNN. (2019). Utang Bpjs Kesehatan Ke Rumah Sakit Tembus Rp21,16 Triliun, Jakarta: CNN Indonesia. Https:// Www.Cnnindonesia.Com/Ekonomi/20191120102006-78-449889/Utang-Bpjs-Kesehatan-Ke-RumahSakit-Tembus-Rp2116-Triliun

Department Of Health And Social Care. (2012), Guidance Nhs Constitution For England, United Kingdom: Department Of Health And Social Care. Retrieved from Https:/Www.Gov.Uk/Government/Publications/ The-Nhs-Constitution-For-England

INFO BPJS Kesehatan. (2019). Strategi Mewujudkan Jaminan Kesehatan Berkualitas, Edisi 07. Jakarta: BPJS Kesehatan.

NHS Constitution. (2015). Guidance The Nhs Constitution For England, Inggris Raya: Department Of Health \& Social Care, 14 Oktober 2015, Retrieved from Https:/Www.Gov.Uk/Government/Publications/The-NhsConstitution-For-England/The-Nhs-Constitution-For-England

Pavolini, E., \& Vicarelli, G. (2012), Is Decentralization Good For Your Health? Transformations In The Italian NHS. Current Sociology. 60(4), 472-488. Retrieved from Https://Doi.Org/10.1177/0011392112438332

Pramana, J. A., Arso, S. P., \& Kusumastuti, W. (2018). Analisis Upaya Kepatuhan Hukum Dalam Memenuhi Hak Dan Kewajiban Pasien Bpjs Kesehatan Di Rsud Ungaran. Jurnal Kesehatan Masyarakat (E-Journal). 6(5), 95-103. Retrieved from Https://Ejournal3.Undip.Ac.Id/Index.Php/Jkm/Article/View/21982

Rachmawati, I. N. (2010). Kajian Kebijakan Jaminan Kesehatan Masyarakat. Jurnal Keperawatan Indonesia. 13(2), 98-104. Retrieved from http://dx.doi.org/10.7454/jki.v13i2.238

Suhanda, R. (2015). Jaminan Kesehatan Dan Managed Care. Jurnal Kedokteran Syiah Kuala.15(2), 104-113. Retrieved from Http://Www.Jurnal.Unsyiah.Ac.Id/Jks/Article/View/3262

Widiastuti, I. (2018). Pelayanan Badan Penyelenggara Jaminan Sosial (Bpjs) Kesehatan Di Jawa Barat. Jurnal 
Comparative Study on The Contribution Payment System in BPJS With A Tax System-Based Regulation In NHS

Ilmiah (E-Journal), 4(3). Retrieved from Http://E-Journal.Jurwidyakop3.Com/Index.Php/Jurnal-Ilmiah/ Article/View/282 